Primljen / Received: 20.5.2013. Ispravljen / Corrected: 25.6.2013.

Prihvaćen / Accepted: 30.7.2013.

Dostupno online / Available online: 10.9.2013.

\section{Analysis of building damage caused by earthquakes in Eastern Turkey}

\section{Authors:}

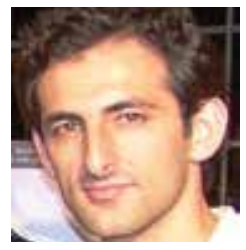

Cumhur Coşgun, MSc. CE Istanbul Kultur University Department of Civil Engineering cumhurcosgun@gmail.com

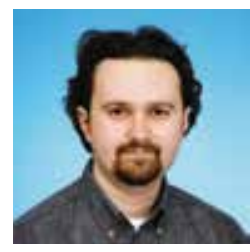

Assist.Prof. Ahmet Anıl Dindar, PhD. CE Istanbul Kültür University Department of Civil Engineering a.dindar@iku.edu.tr

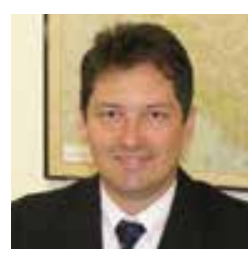

Edip Seçkin, PhD. CE Istanbul Kültür University Department of Civil Engineering e.seckin@iku.edu.tr

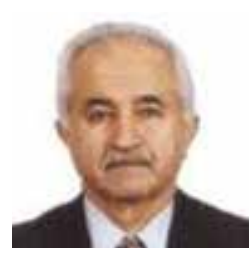

Prof. Yusuf Hatay Önen, PhD. CE Istanbul Kültür University Department of Civil Engineering y.onen@iku.edu.tr

\section{Cumhur Coşgun, Ahmet Anıl Dindar, Edip Seçkin, Yusuf Hatay Önen}

Professional paper

\section{Analysis of building damage caused by earthquakes in Eastern Turkey}

Numerous ground motions of various intensities have been registered in Eastern Turkey since 23 October 2011. Two of them resulted in severe loss of life and great material damage in the towns of Van and Erciş. More than 600,000 people were affected by damage caused by earthquakes in that period. Van is one of the most recent and fastest developing regions of Turkey, which is why thorough investigations must be made to check seismic properties of buildings erected in this region. Types of seismic damage inflicted on buildings, and causes of damage to various buildings built in Van and Erciş, are analysed in the paper.

\author{
Key words: \\ earthquakes, Eastern Turkey, seismic effects on buildings, quality of materials
}

Stručni rad

Cumhur Coşgun, Ahmet Anıl Dindar, Edip Seçkin, Yusuf Hatay Önen

\section{Analiza oštećenosti zgrada stradalih tijekom potresa na istoku Turske}

Od 23. listopada 2011. do danas u istočnoj Turskoj svjedočili smo brojnim pomicanjima tla različite jačine. Dvije takve pojave u gradovima Vanu i Ercişu odnijele su mnoge živote i uzrokovale veće materijalne štete. Više od 600.000 ljudi osjetilo je posljedice potresa u tom razdoblju. Van je jedna od najnovijih i najbrže izgrađenih pokrajina Turske, te je potrebno temeljito ispitati karakteristike gradevina navedene regije u kontekstu potresa. U članku se analiziraju vrste oštećenja zgrada uslijed potresa te uzroci nastajanja oštećenja na različitim građevinama u Vanu i Ercişu.

Ključne riječi:

potresi, istočna Turska, učinci potresa na gradevine, kvaliteta materijala

Fachbericht

Cumhur Coşgun, Ahmet Anıl Dindar, Edip Seçkin, Yusuf Hatay Önen

\section{Analyse der durch Erdbeben in der Osttürkei verursachten Gebäudeschäden}

Seit dem 23. Oktober 2011, bis heute, hat sich eine Reihe von Erdbeben verschiedener Stärke in der Osttürkei ereignet. Zwei dieser Vorfälle in den Städten Van und Erciş haben zahlreiche Menschenleben gefordert und bedeutende Sachschäden verursacht. Mehr als 600000 Menschen sind in diesem Zeitraum von den Folgen der Erschütterungen betroffen worden. Van ist eines der kürzlich und schleunig ausgebauten Gebiete in der Türkei; daher ist es notwendig die Eigenschaften der Gebäude in dieser Region gründlich im Bezug auf Erdbebeneinwirkungen zu erforschen. Diese Arbeit analysiert verschiedene durch Erdbeben in Van und Erciş entstandene Gebäudeschäden und ihre möglichen Entstehungsursachen.

\section{Schlüsselwörter:}

Erdbeben, Osttürkei, Erdbebeneinwirkungen auf Gebäude, Materialsqualität 


\section{Introduction}

Starting from the Saturday evening of 22 October 2011 and until the end of February, numerous ground motions of more than 3.0 in magnitude were recorded in Eastern Turkey. In the scope of these ground motions, two significant large earthquakes occurred on 23 October 2011, Sunday, 1.41 (EEST) pm, and 9 November 2011, Wednesday, 9.23pm (EEST), at Tabanli village to the north, and off the Edremit coast to the southwest of the city of Van, respectively. These two earthquakes caused major building damage and collapse, as well as a considerable loss of life and economic losses, mostly in the town of Erciş and in the city of Van, Table 1.

In 1972, McKenzie discussed the theory about continuous movement of Anatolia in the East-West direction due to the pressure exerted by the Arabian Peninsula, Figure 1.

Recently, the observations via the Continuously Operating GPS Stations have shown that Anatolia moves at the rate of $20 \mathrm{~mm}$ annually, Figure 2 [1]. Hence, numerous active fault lines are found all around Anatolia. The region of strong ground motions in Eastern Turkey, with two earthquakes evaluated in this study, is marked as box in Figure 2.

As can be seen in Table 2, [2], the first earthquake (23 October 2011, $M_{w}=7.2$ ) caused more damage and loss of life in the town of Ercis, compared to the city of Van that is closer to the epicentre.

It is interesting to note that even though Van is almost at the same distance from both epicentres, Figure 3, the second earthquake, although characterized by a smaller magnitude, caused more building collapse and damage compared to the first one. This study aims to find out the reasons for this occurrence.

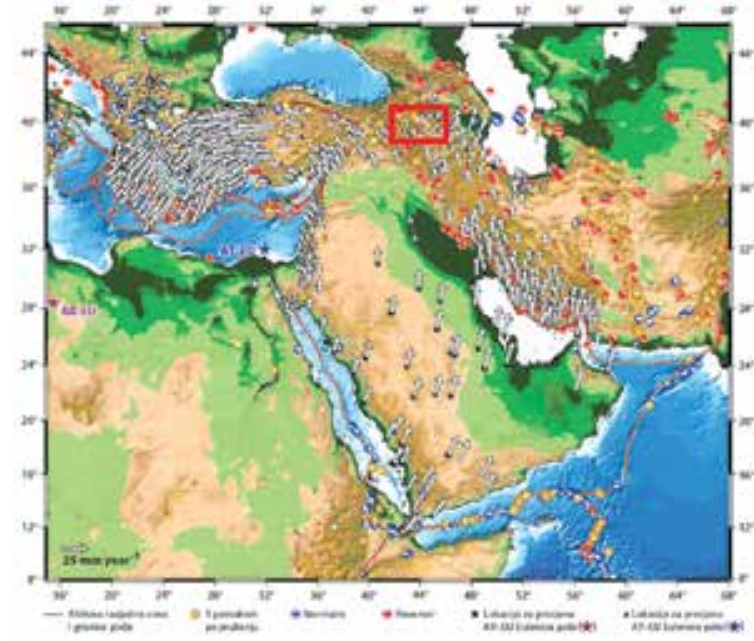

Figure 1. Tectonic structure of Turkey and its surroundings $[3,4]$

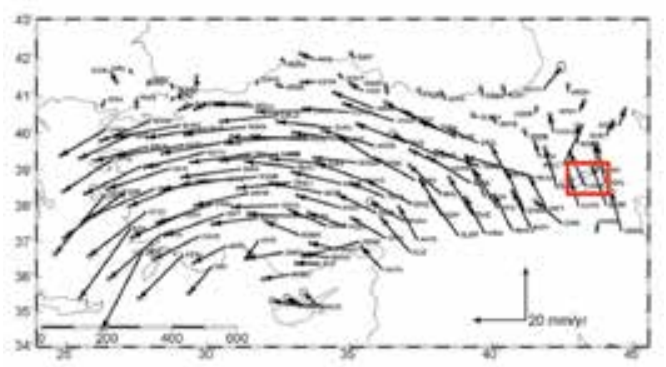

Figure 2. Velocity field obtained from the observations of the National Continuously Operating Reference Stations (CORS-TR) established in 2009.

Table 1. Information about the earthquakes

\begin{tabular}{|c|c|c|c|c|}
\hline Earthquakes & \multicolumn{2}{|c|}{ 23 $^{\text {rd }}$ October 2011 } & \multicolumn{2}{c|}{$9^{\text {th }}$ November 2011 } \\
\hline Recorded by & $\begin{array}{c}\text { Kandilli Observatory and } \\
\text { Earthquake Research Institute } \\
\text { (KOERI) }\end{array}$ & $\begin{array}{c}\text { U.S. Geological } \\
\text { Survey } \\
\text { (USGS) }\end{array}$ & $\begin{array}{c}\text { Kandilli Observatory and } \\
\text { Earthquake Research Institute } \\
\text { (KOERI) }\end{array}$ & $\begin{array}{c}\text { U.S. Geological } \\
\text { Survey } \\
\text { (USGS) }\end{array}$ \\
\hline Location & $\begin{array}{c}\text { Tabanli village in the north } \\
\text { of Van } \\
\text { Latitude }\end{array}$ & Eastern Anatolia & $\begin{array}{c}\text { Off the Edremit coast in the } \\
\text { southwest of Van }\end{array}$ & EasternAnatolia \\
\hline Longitude & $43.757 \mathrm{~N}$ & $38.691 \mathrm{~N}$ & $38.429 \mathrm{~N}$ & $38.42 \mathrm{~N}$ \\
\hline Focal depth & $5 \mathrm{~km}$ & $43.497 \mathrm{E}$ & $43.234 \mathrm{E}$ & $5.22 \mathrm{E}$ \\
\hline $\mathrm{M}_{\mathrm{w}}$ & 7.2 & $16 \mathrm{~km}$ & $5 \mathrm{~km}$ & $5 \mathrm{~km}$ \\
\hline
\end{tabular}

Table 2. Loss of life and building collapse [2]

\begin{tabular}{|c|c|c|c|c|c|c|c|}
\hline \multirow{2}{*}{ City } & \multirow{2}{*}{$\begin{array}{l}\text { Population } \\
\text { (2010) }\end{array}$} & \multicolumn{3}{|c|}{$\begin{array}{c}\text { First earthquake } \\
\text { (23 } 3^{\text {rd }} \text { October } 2011 \text { and } \mathrm{M}_{\mathrm{w}}=7.2 \text { ) }\end{array}$} & \multicolumn{3}{|c|}{$\begin{array}{c}\text { Second earthquake } \\
\text { ( } 9^{\text {th }} \text { November } 2011 \text { and } M_{w}=5.6 \text { ) }\end{array}$} \\
\hline & & Fatalities & Injured & $\begin{array}{l}\text { Buildings } \\
\text { Collapsed }\end{array}$ & Fatalities & Injured & $\begin{array}{l}\text { Buildings } \\
\text { Collapsed }\end{array}$ \\
\hline Van & 540.000 & 100 & 350 & 10 & 40 & N/A & 18 \\
\hline Erciş & 77.000 & 351 & 750 & 100 & 0 & 0 & 0 \\
\hline Rural area & N/A & 153 & 201 & 2197 & 0 & 0 & 0 \\
\hline
\end{tabular}




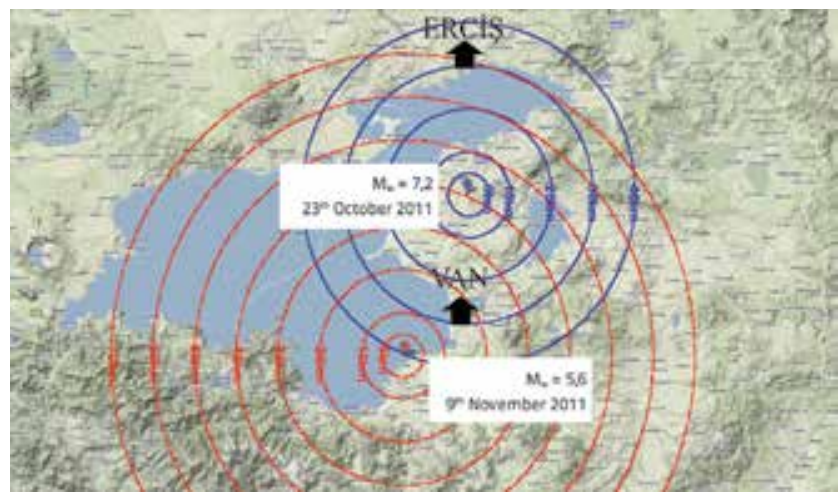

Figure 3. Locations of the Van and Erciş earthquakes

\section{Evaluation of strong ground motion records}

The city of Van is located in a highly seismic region at the extension of the North and East Anatolian Fault lines. In this region, the faults are mostly characterized by the strike-slip mechanism, Figure 4.

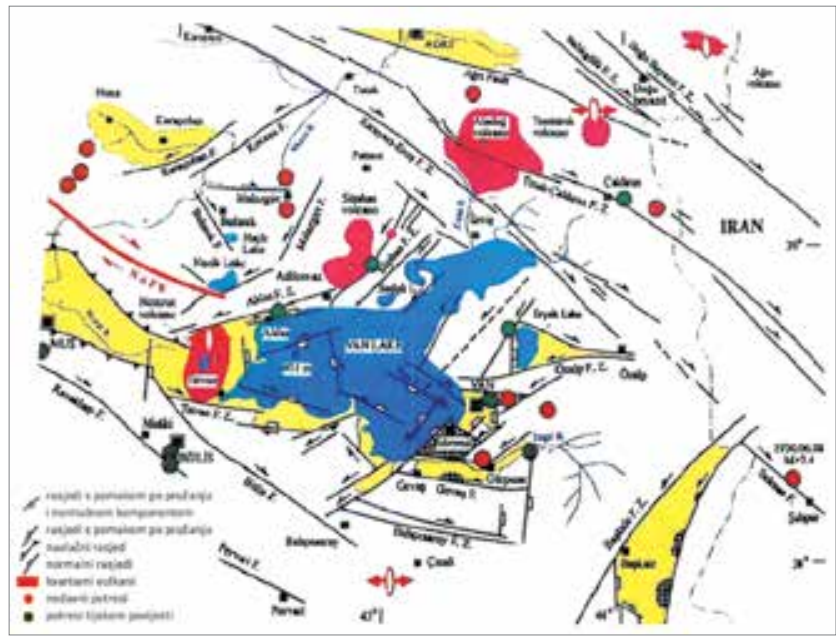

Figure 4. Active fault lines in the vicinity of Van [5]

a)

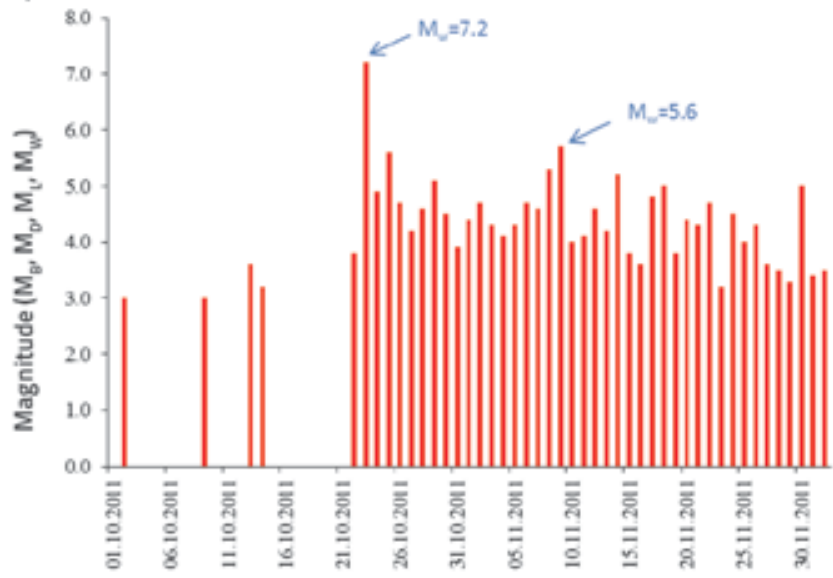

Prior to the first earthquake (23 October 2011, $\mathrm{M}_{\mathrm{w}}=7.2$ ), a limited number of ground motions (Magnitude $\geq 3.0$ ) were recorded [6], Figure $5 \mathrm{a}$. In the 72 hours following the first earthquake, this number sharply increased to 570 , Figure $5 \mathrm{~b}$. In the following 10 days, the number of ground motions decreased. Prior to the second earthquake ( 9 November 2011, $M_{w}=5.6$ ), there was a slight increase in the number of strong ground motions. The second earthquake struck in the Southwest of Van and caused a more severe building collapse. The waveforms recorded by the closest recording stations, Figure 6 , were obtained from the National Earthquake Digital Record Database [7] so that the destructiveness of the earthquakes can be identified.

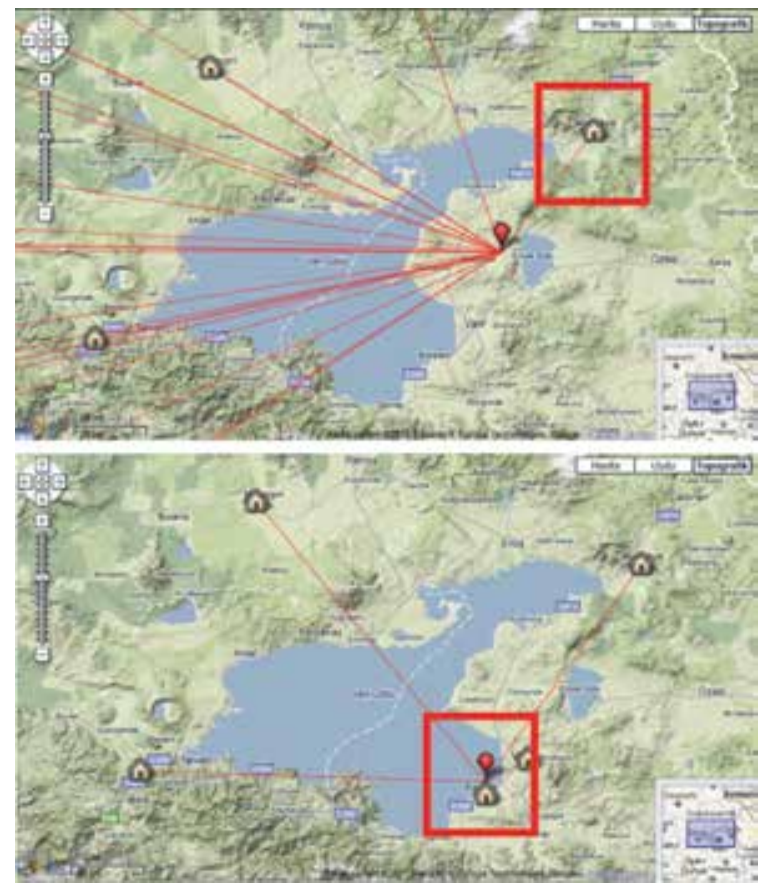

Figure 6. Location of the strong ground motion recording stations, (left and right are Muradiye Meteorology and Edremit Health Centre for the $1^{\text {st }}$ and $2^{\text {nd }}$ earthquakes, respectively)

b)

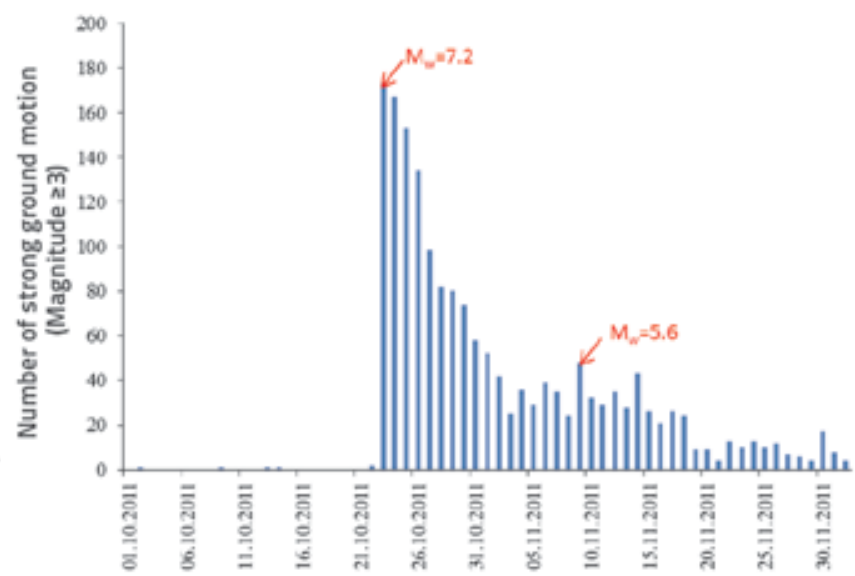

Figure 5. Distribution of strong ground motions in the vicinity of Van between $1^{\text {st }}$ October and $2^{\text {nd }}$ December 2011 
Table 3. Properties of filtered waveforms recorded at each earthquake

\begin{tabular}{|c|c|c|c|c|c|}
\hline Earthquake & $\begin{array}{l}\text { Record time } \\
\text { (Local time) }\end{array}$ & $\begin{array}{l}\text { SGM Station name } \\
\text { (Coordinates) }\end{array}$ & $\begin{array}{c}\text { Record time } \\
\text { (Effective duration) }\end{array}$ & $\begin{array}{c}\text { PGA }\left(\mathrm{cm} / \mathrm{s}^{2}\right) \\
N-S \\
E-W \\
\text { Up }\end{array}$ & $\begin{array}{c}\text { PGV (cm/s) } \\
N-S \\
\text { E-W } \\
\text { Up }\end{array}$ \\
\hline $\begin{array}{l}23^{\text {rd }} \text { October } 2011 \\
\qquad\left(\mathrm{M}_{\mathrm{w}}=7,2\right)\end{array}$ & $13: 41: 20$ & $\begin{array}{c}\text { Muradiye } \\
\text { Meteorology } \\
(38,99011 \mathrm{~N}-43,76302 \mathrm{E})\end{array}$ & $\begin{array}{c}38,85 \mathrm{~s} \\
(22,29 \mathrm{~s} \\
\text { E-W component) }\end{array}$ & $\begin{array}{c}195,49 \\
167,18 \\
80,51\end{array}$ & $\begin{array}{c}26,95 \\
17,45 \\
6,22\end{array}$ \\
\hline $\begin{array}{l}9^{\text {th }} \text { November } 2011 \\
\qquad\left(M_{w}=5,6\right)\end{array}$ & $21: 23: 33$ & $\begin{array}{c}\text { Edremit Health Centre } \\
\text { Basement } \\
(38,41450 \mathrm{~N}-43,26820 \mathrm{E})\end{array}$ & $\begin{array}{c}34,58 \mathrm{~s} \\
(17,57 \mathrm{~s} \\
\mathrm{N}-\mathrm{S} \text { component })\end{array}$ & $\begin{array}{c}69,28 \\
103,08 \\
44,85\end{array}$ & $\begin{array}{c}118,59 \\
137,70 \\
43,53\end{array}$ \\
\hline
\end{tabular}

PGA - Peak Ground Acceleration; PGV - Peak Ground Velocity

Among the available waveform records, two raw records were selected and subjected to baseline correction as well as to 0.1$25 \mathrm{~Hz}$ Butterworth band filtering by using the SeismoSignal program, [8]. The information about the filtered waveforms is given in Table 3.

The effective durations of both waveforms were calculated using the method introduced by Trifunac and Brady [9], that takes into account the part between the 5 to 95 per cent of the Arias Intensity values. All three components of both waveforms were evaluated and the longest effective durations were assumed as the duration of the earthquakes, Figure7.

As seen from the waveforms, the Peak Ground Acceleration (PGA) of the recorded motions are $0.20 \mathrm{~g}\left(195.49 \mathrm{~cm} / \mathrm{s}^{2}\right)$ and
$0.11 \mathrm{~g}\left(103.08 \mathrm{~cm} / \mathrm{s}^{2}\right)$ for the first and second earthquakes, respectively. These values and the duration of the excitation are not capable of causing a major destruction. In addition to that, the spectral values of the wave forms are quiet lower than the design spectrum (for $5 \%$, [10]), Figure 8 . The design spectrums in Figure 8 are depicted according to the soil classes given in [10]. Van province is located in a highly seismic zone in Turkey. The normalized response spectrum values are higher than the normalized design values specified in the [10]. Therefore, the damage and collapse of structures during the two earthquakes can be related to structural deficiencies due to poor engineering and low quality of construction material. Such deficiencies were indeed observed in the course of field investigations [11].
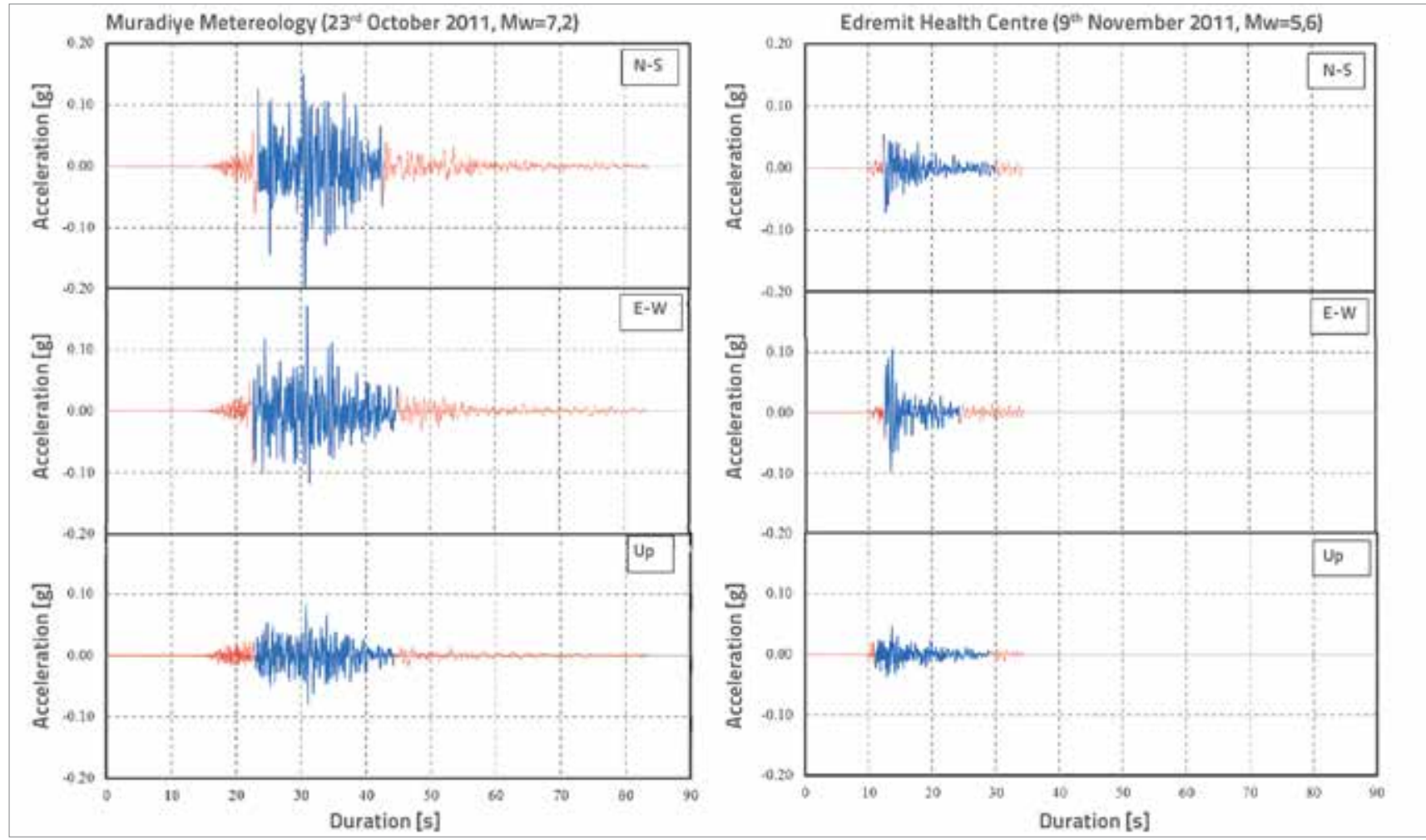

Figure 7. Acceleration waveforms for the first and second earthquakes (dark part of the waveforms represents the effective duration) 

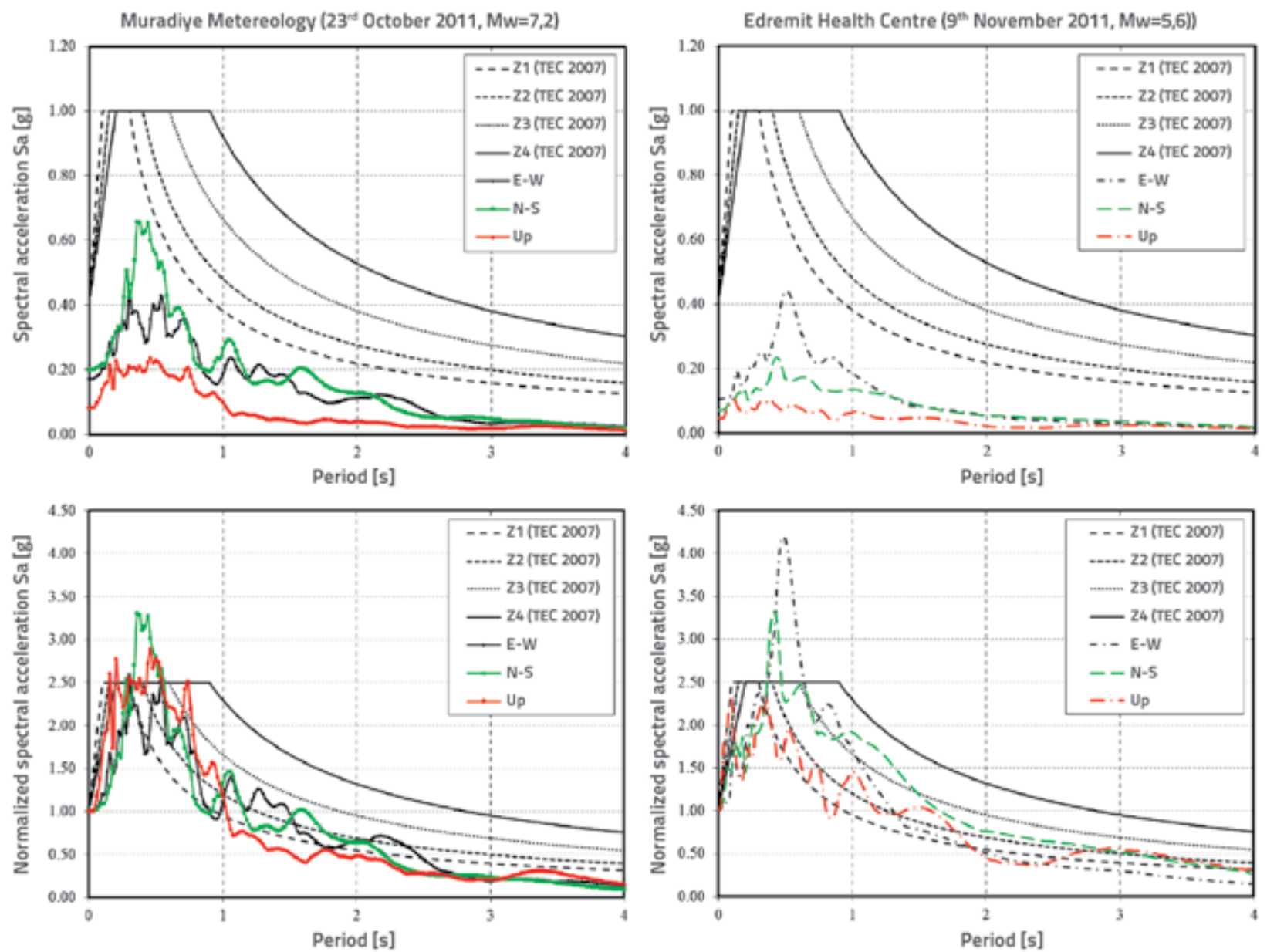

Figure 8. Comparison of response spectra of both earthquake records with the design spectrum given in Turkish Earthquake Code (2007) [10], (top line spectral curves, bottom line normalized spectral curves)

\section{Damages observed}

The town of Erciş was mainly affected by the first earthquake, with the magnitude of $M_{w}=7.2$, which occurred on 23 October 2011. The town is located approximately $30 \mathrm{~km}$ to the north of the epicentre, Figure 3, and the building stock mostly consists of 4 to 6 story reinforced concrete structures built before 1997 when the Turkish Earthquake Code was significantly improved. The majority of property loss in the town is concentrated in the downtown area, where the buildings are much older than the buildings at the outskirts of Erciş. In addition, due to lack of legal inspection, most of the buildings in the town have more than the maximum number of storeys defined by local authorities. It was reported that no life or property loss occurred during the second earthquake.

Unlike the town of Erciş, Van was affected by both earthquakes. The magnitude of the second earthquake that occurred on 9 November 2011 was lower $\left(M_{w}=5.6\right)$ and it was characterized by the less effective duration then the first earthquake, Figure 7. The epicentre was approximately $15 \mathrm{~km}$ to the southeast of the city, Figure 3. Consequently, the partial or extensive damage, ranging from partition wall separation to total collapse of buildings, affected almost every building in the city.

Structural and non-structural damage observed on the buildings in Van and Erciş is presented in the following section.

\subsection{Damage to structural elements}

Structural elements are designed to withstand static and dynamic forces under various circumstances such as excessive gravity loads and earthquakes. It would be desirable for permanent damage to occur at the end of the beams, while the columns should remain elastically intact. In this way, the total collapse of the buildings would be prevented and people inside the building could be evacuated without any loss. However, the observations regarding earthquakes that hit the city of Van and the town of Erciş have revealed that most of the heavily damaged buildings have the RC beams which are stronger than the columns, contrary to the above mentioned principle. This proves that acceptable structural behaviour has not been provided for in the design and construction of buildings in this area. 


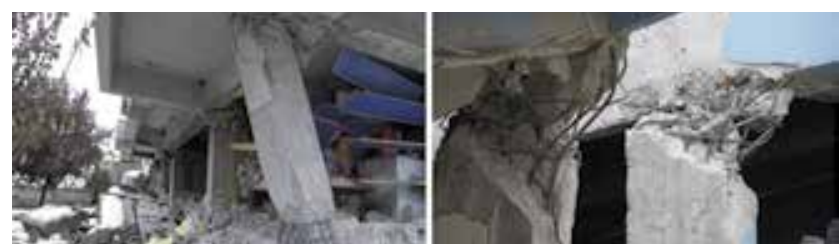

Figure 9. Examples of plastic rotations at the end of columns instead of beams in Erciş

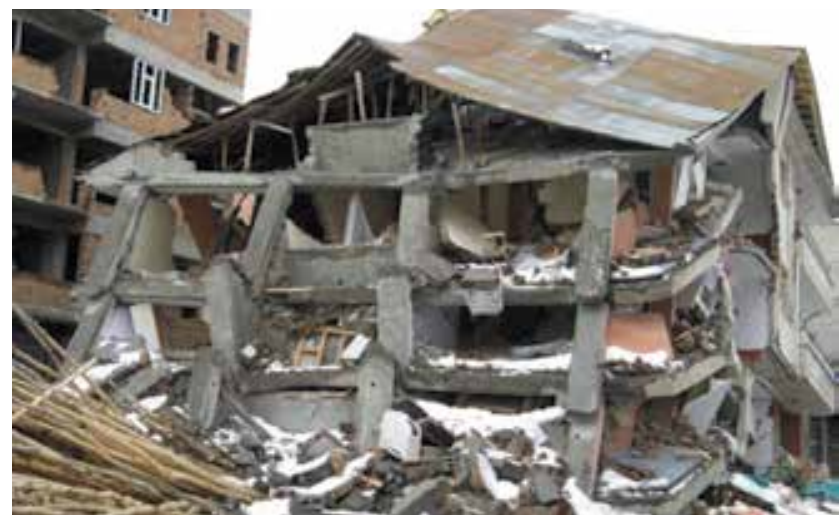

Figure 10. Total collapse of a building in Erciş due to sway mechanism after plastic rotation at the end of each column of individual storeys

Thebeam-columnjoints arethemostvulnerable parts of thestructural system when the latter is subjected to lateral loading actions, such as those occurring during earthquakes. To provide for an adequate rotation and shear capacity, the detailing of the reinforcement is of highest significance. In particular, the lateral reinforcement of longitudinal rebars of the columns must be continued throughout the height of the joint. However, this reinforcement was not done in almost every damaged building, Figure 11.
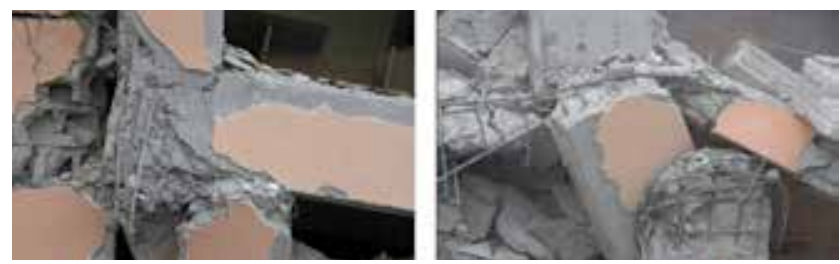

Figure 11. Typical failure at the joints of a multistorey building in Erciş

Mostly owing to the difficulty in placing longitudinal rebars of beams on the top of the columns, the stirrups were usually not installed along the height of the beams at the joints. This defect is unfortunately one of the main reasons for failure of structural systems, even though the beam and columns remain intact after the quake.
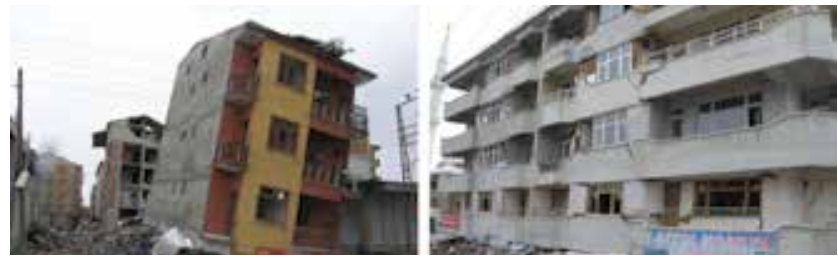

Figure 12. Collapse of two buildings due to soft storey effect at the ground floor level in Erciş
Buildings adjacent to streets are usually used for both commercial and residential purposes. To provide enough space at the ground floor, the storey height is generally higher than that of the upper floors and also, there are no infill walls at the street side of the ground floor, because of the need to provide for better visibility of the commercial area. However, this fact causes a soft storey effect in case of multi-storey buildings. Due to the lack of lateral stability at the ground floor level, the building sways up to the limit of the lateral deformation capacity of the columns at the ground floor, resulting in collapse of the entire soft storey, Figure 12.

Modern seismic design codes prevent shear failure of columns by prescribing a certain amount of confinement around longitudinal rebars. However, if the shear span of flexural elements is shortened for some construction related reasons, the structural element is prone to excessive shear forces rather than flexural forces. As a result, during the quakes, the diagonal shear cracks occur along the free height of the flexural element, Figure 13. Such damage could create undesirable mechanisms at the building's floors.

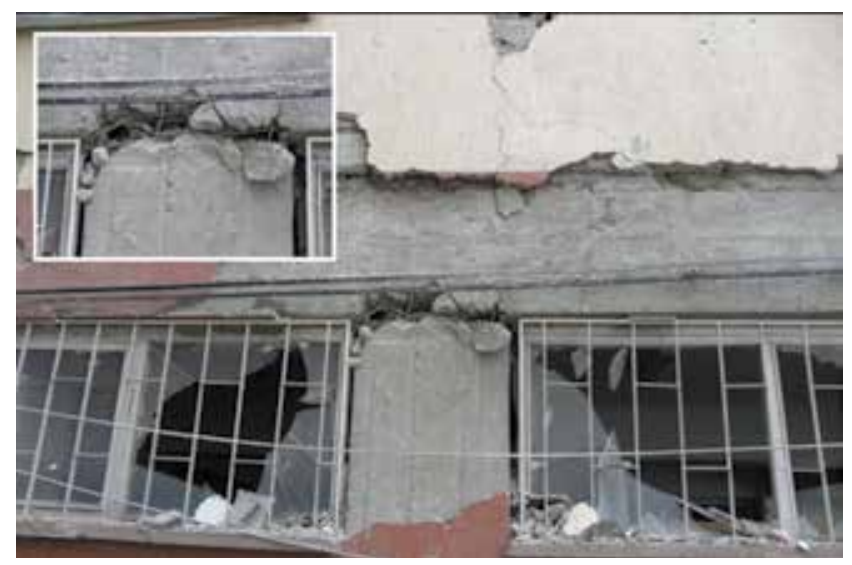

Figure 13. Shear failure at the top of the column due to short shear span in Van

The buildings constructed in the downtown of Van and Erciş are row house style buildings situated along both sides of the streets. Unfortunately, the lack of regulations on the height of buildings creates a practical problem of having different story heights, as shown in Figure 14. Hence, during ground shaking, the rigid floor of one building may hammer at the middle of the columns of the adjacent building. Such lateral forces acting on the columns lead to disastrous drop of the column stability and, accordingly, to the collapse of the entire slab above.

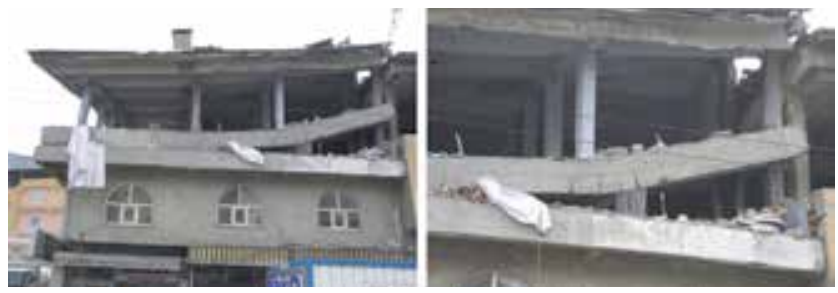

Figure 14. Partial collapse of the slab due to pounding in Erciş 
In medium to high density housing areas of Van and Erciş, many more buildings are affected by the impact of collapsing buildings, Figure 15. Buildings of low construction quality or buildings built contrary to relevant regulations are subjected to heavy damage during a strong ground shaking activity. In case of partial or total collapse of such buildings, it is quite possible that they will fall on neighbouring buildings that may have survived the quake. Unfortunately, no precautions can be taken to prevent such an event, except for effective inspections during the design and construction of buildings.
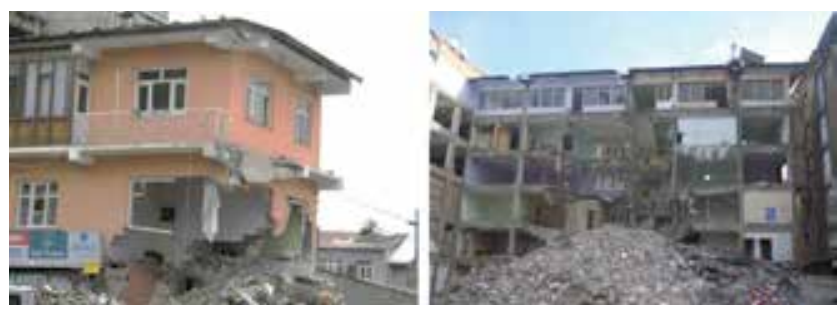

Figure 15. Damage due to the impact of the collapsed building on the neighbouring building in Erciş and Van

Selection of the structural system and elements is a crucial engineering decision in earthquake prone areas. Therefore, the practicing engineer must have experience in the earthquake resistant design of structures. Even if service loads do not inflict any damage on a poorly designed building, the earthquake load may exceed the bearing capacity of the element, and ultimately lead to catastrophic results, Figure 16.

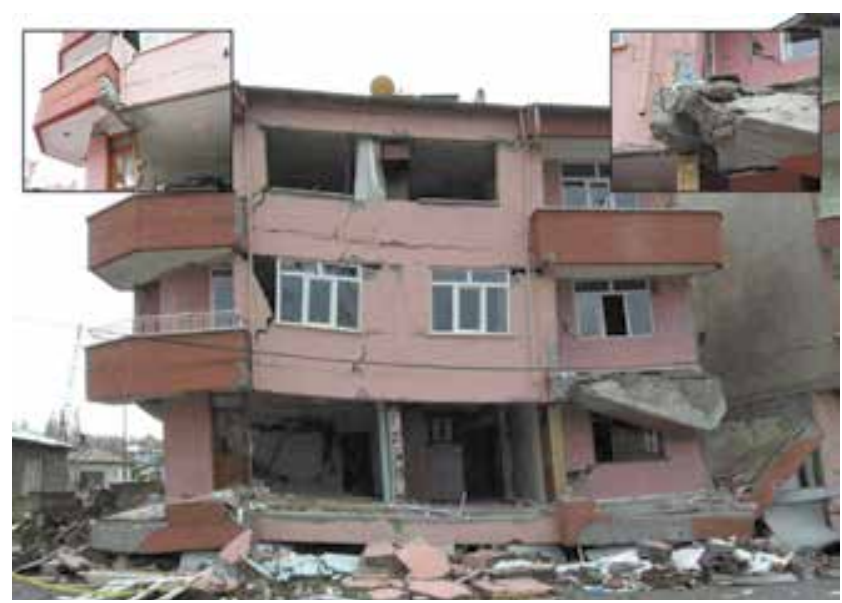

Figure 16. Damage due to selection of an improper structural system in Erciş

\subsection{Damage to non-structural elements}

Although infill walls do not bear any load in a structural system, they still may suffer extensive damage during an earthquake. The main purpose of infill walls is to physically separate rooms within a story, and to protect the building interior from external elements. Because of severe weather conditions in Eastern Turkey, external infill walls of buildings are made of double brick walls with thermal insulation inside,
Figure 17. Although structural systems of buildings were not damaged during the first earthquake in the city of Van, almost every building had diagonal cracks and out of plane deformations on outer walls, which is due to the total lack of mechanical bond between the double brick layers.

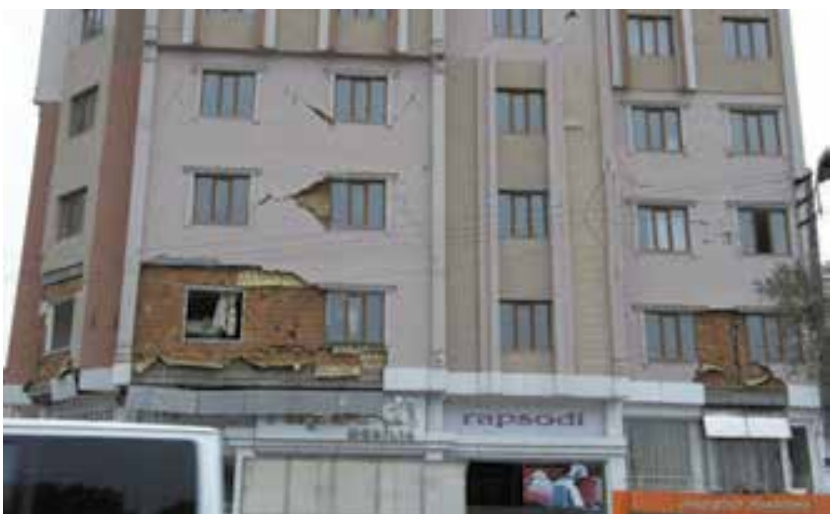

Figure 17. Diagonal damage patterns occurred at the infill sandwich walls in city of Van

Due to the severe winter conditions, or in order to enable the use of attic space, the roofs are significantly elevated and inclined. Therefore, the walls under gable roofs are accordingly high, which causes out-of-plane stability problems. In addition to that, the lack of tie beams at the top of gable walls is yet another reason for an insufficient stability, Figure 18. Such construction defects have been observed at almost every building in Van and Erciş.

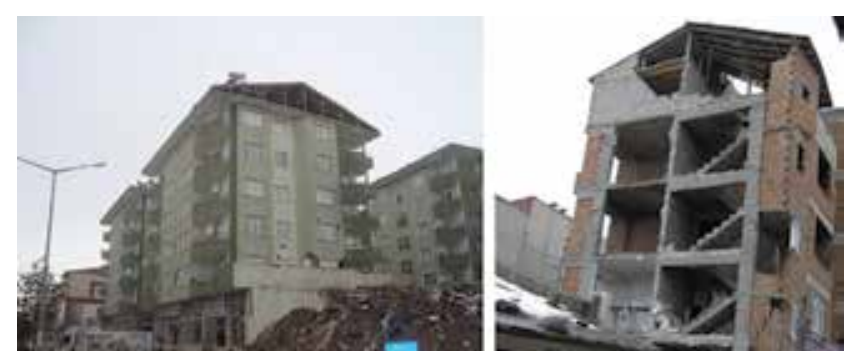

Figure 18. Out-of-plane deformation damage of the gable walls

Structural systems supporting the roof do not usually provide an appropriate lateral stiffness. This situation has additionally deteriorated when water tanks (each about $10 \mathrm{kN}$ ) with solar panels were installed on the top of the roof consequently causing additional seismic mass on the roof structural system. During the earthquakes, the majority of the roofs swayed or fall down from the top of the buildings, Figure 19.
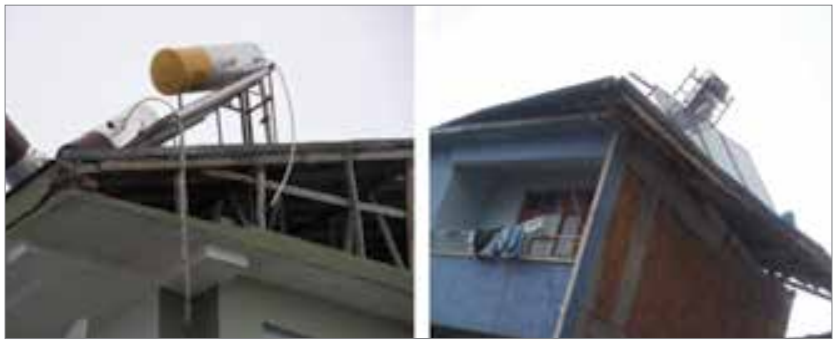

Figure 19. Swayed roofs due to low stiffness and additional seismic masses in Erciş 


\section{Masonry buildings}

In masonry buildings, the lateral stiffness is provided by strong adobe walls and slabs on the walls. In case one of them is insufficiently constructed, a severe damage to masonry buildings during a strong ground motion is unavoidable. The typical damage observed in masonry buildings are diagonal shear cracks and openings on walls, Figure 20.
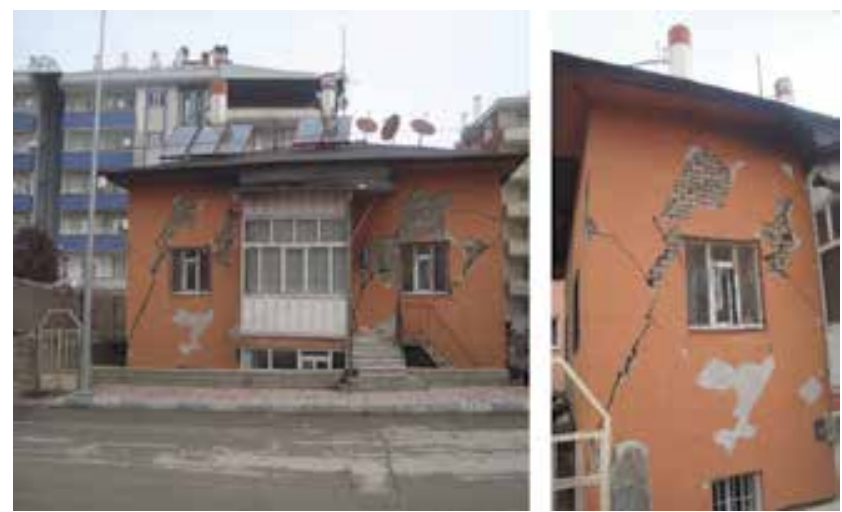

Figure 20. Typical shear damage observed on structural walls of a masonry building in Van

Slabs resting on masonry walls are usually made of earth material filling on wooden beams. The higher the earth material filled, the more lateral force is exerted on the walls, which causes shear openings. This phenomenon was observed at most of the old masonry houses in Van and Erciş. The thickness of the earth fill on the roof reaches up to $40 \mathrm{~cm}$, Figure 21.

The lack of an appropriate connection detail between intersecting walls and roof-wall intersections, and the absence of mortar, lead to an out-of-plane instability of masonry buildings made of natural stones, Figure 22.

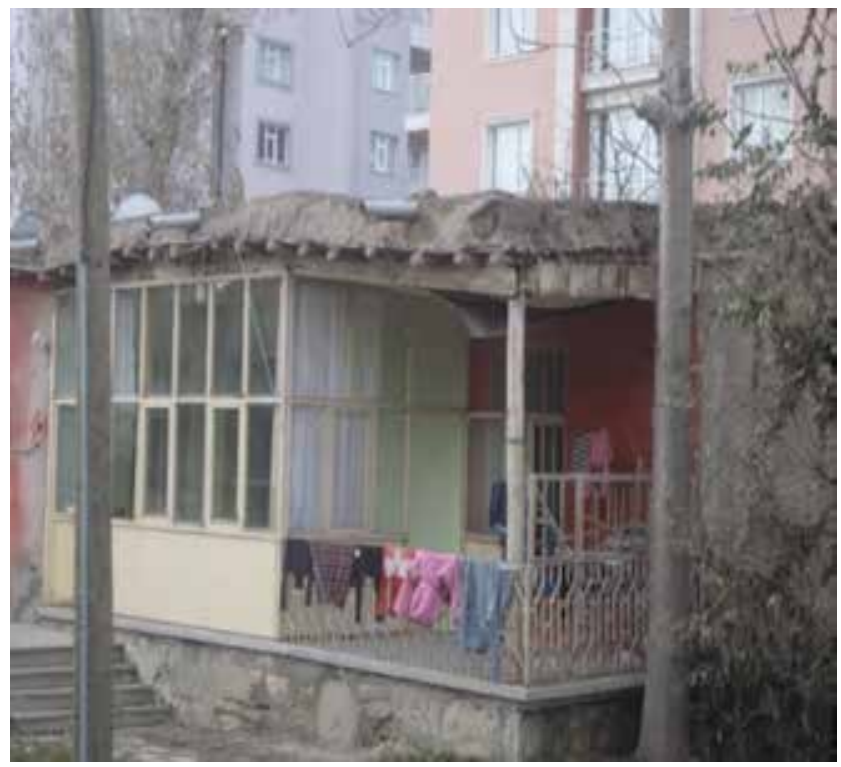

Figure 21. Excessive earthfill on the roof of a masonry building.

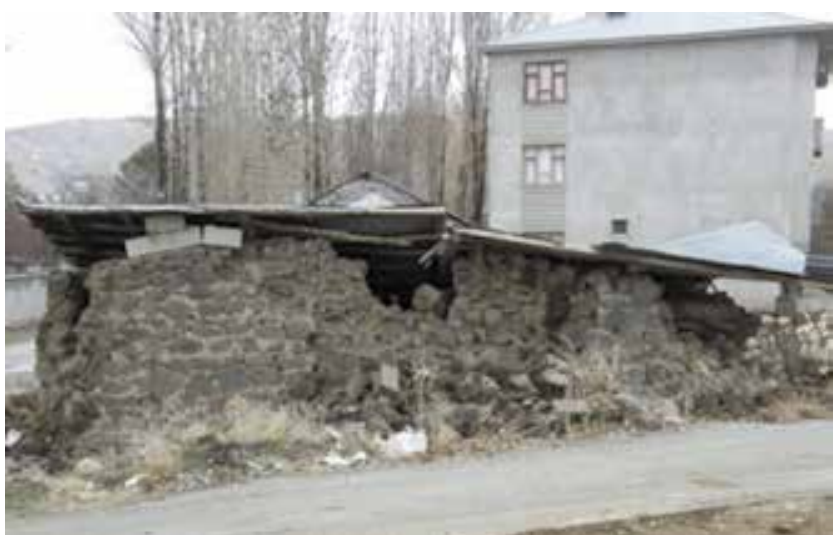

Figure 22. Collapsed masonry building due to the lack of connection and mortar on the walls and roof in Erciş

\section{Minarets}

Minarets built near mosques are exceptionally slender structures. They are made of either block stones or reinforced concrete (RC). The inspection of minaret damage has revealed that the block stone minarets of poor mortar quality lost their stiffness and stability, and totally collapsed. On the other hand, the RC minarets have suffered damage at the parts where there is a change in section geometry or material property, Figures 23 and 24.
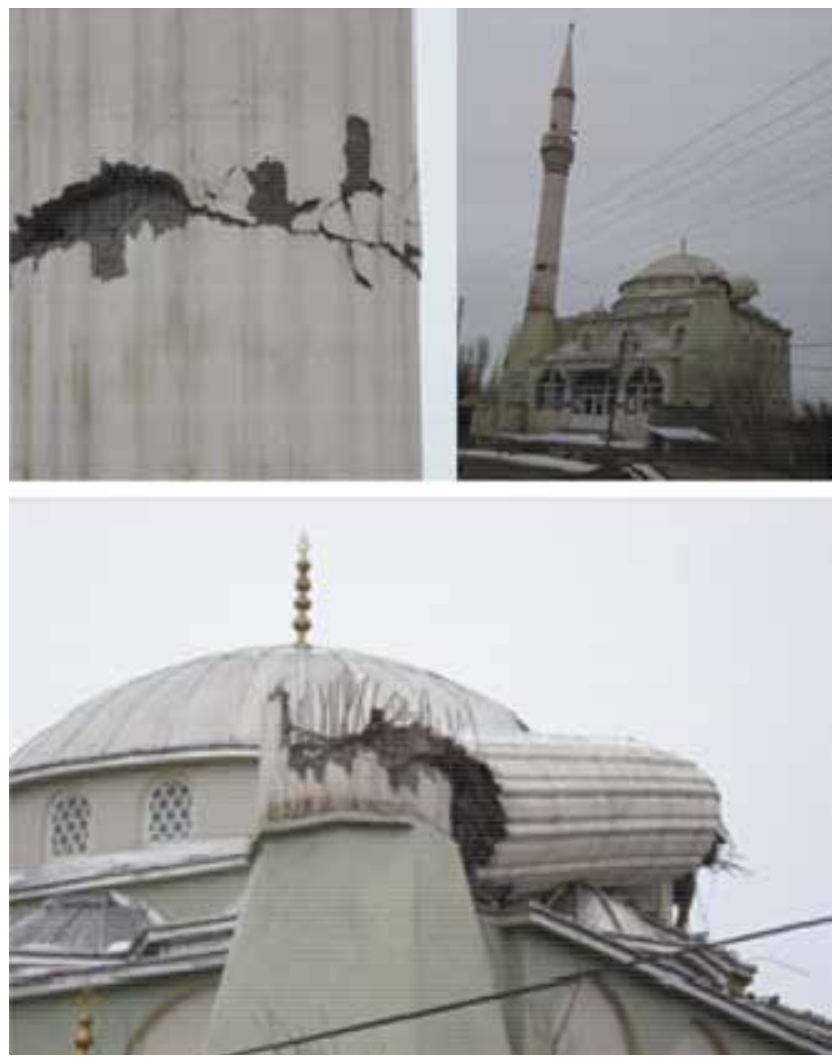

Figure 23. Local damage and two totally collapsed minarets of a mosque in Erciş 


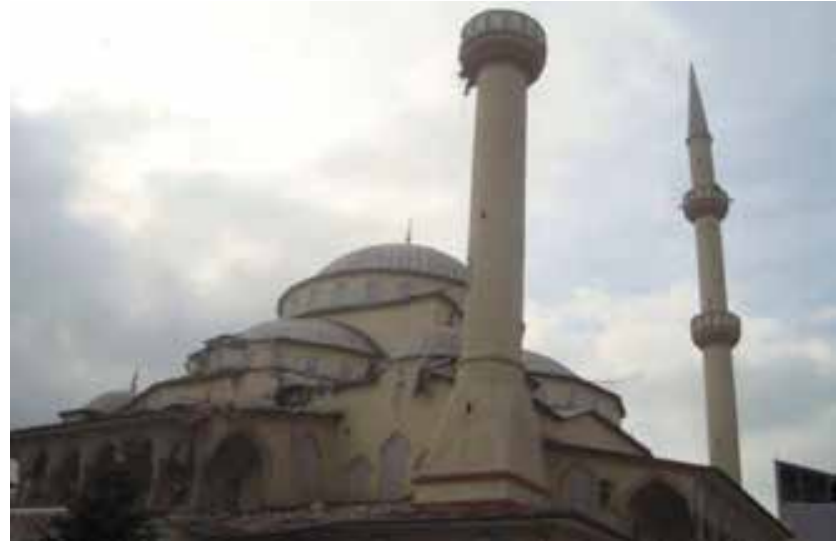

Figure 24. Intact and damaged minarets of a mosque in Van

\section{Material quality and application defects}

\subsection{Concrete quality}

The concrete at the damaged or collapsed buildings displayed a poor quality of the concrete mixture. Aggregates used in the mixture are far from acceptable diameters as stated in Turkish Standards [12], Figure 25 . It is obvious that the aggregates were derived from river beds instead of stone pits. in addition, the cohesion of the cement with the aggregate is almost nonexistent, Figure 26.
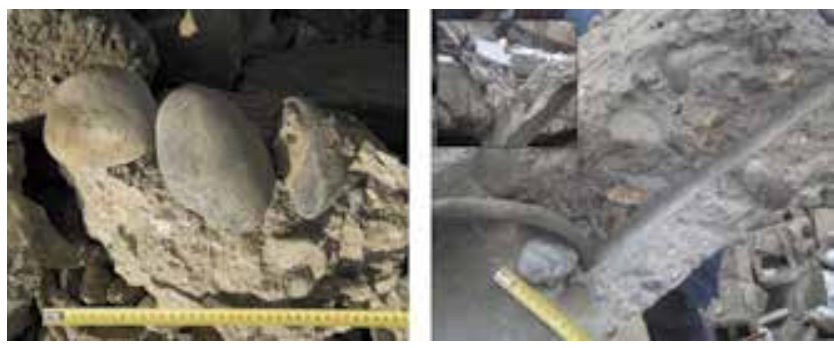

Figure 25. Inappropriate aggregates used in Reinforced concrete buildings
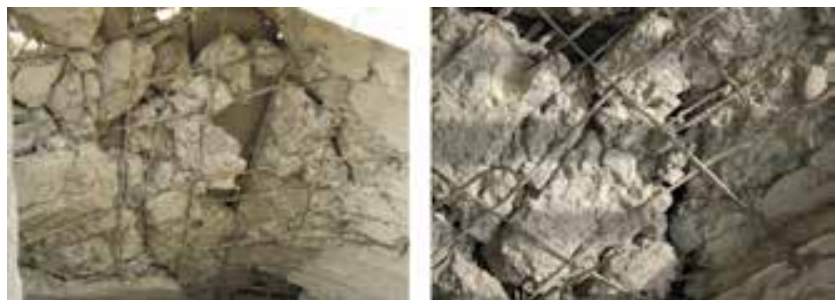

Figure 26. Poor cohesion between cement and aggregate

\subsection{Reinforcement quality}

The study of the damaged or collapsed buildings has revealed that both the longitudinal and lateral reinforcement details at structural elements are not consistent with the code based regulations. For example, the Turkish Earthquake Code (TEC2007) strictly forbids the use of plain rebars as longitudinal reinforcement in earthquake-prone areas. However, most of the multistorey RC buildings that collapsed in Van and Erciş suffered from the poor-bonding problem, Figure 27.
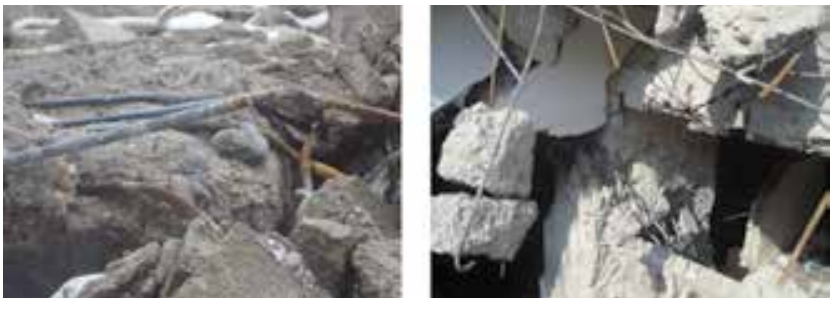

Figure 27. The use of plain reinforcement as longitudinal rebars in RC beams and columns

In case of reversed cyclic deformations, the confinement of the $\mathrm{RC}$ beams and columns is very crucial for maintaining adequate resistance of longitudinal rebars to shear forces. Therefore, lateral reinforcement intervals along RC elements are limited to $10-20 \mathrm{~cm}$ and $15 \mathrm{~cm}$ for the columns and beams, respectively, [10], Figure 28. In the majority of the damaged or collapsed buildings, structural elements did not have a sufficient quantity of lateral reinforcement. In addition, the hooks at the end of the rebars were also either missing or were not arranged at 135 degrees as required by the codes, Figure 29.
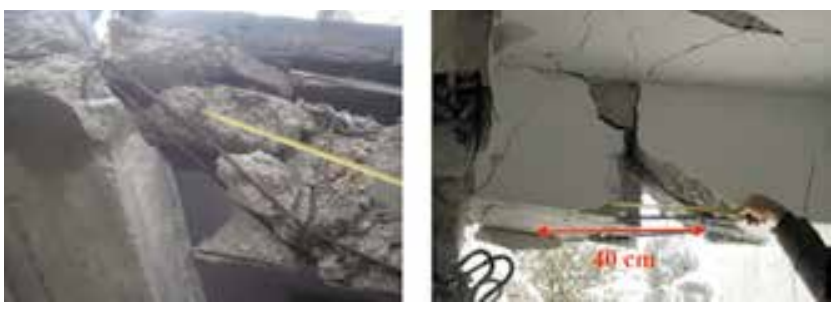

Figure 28. Inadequate lateral reinforcement intervals
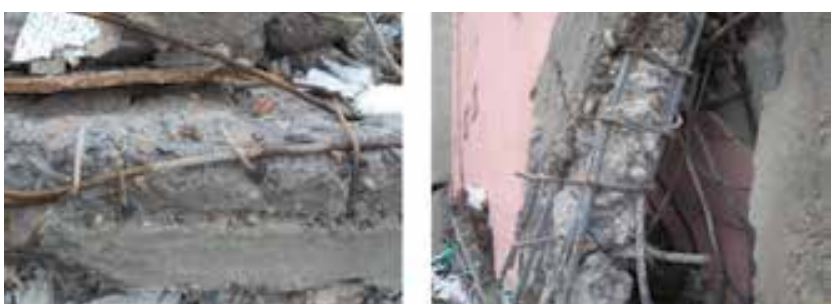

Figure 29. Poor hook arrangements at the end of lateral confinement bars

In case of structural elements with insufficient lateral rebar intervals, the buckling of longitudinal rebars may occur when such elements are subjected to severe shear forces, Figure 30.

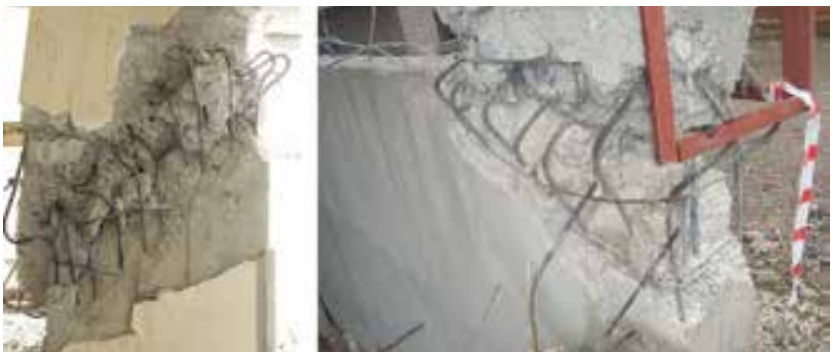

Figure 30. Shear damage and buckling of longitudinal reinforcement due to insufficient lateral rebar interval 


\section{Conclusions}

Starting from $22^{\text {th }}$ October 2011, strong ground motions of various intensities occurred in the east part of Lake Van where the city of Van and the town of Ercis are located. Two of these ground motions, the first one registered on $23^{\text {rd }}$ October $2011\left(M_{w}=7.2\right)$ and the second on $9^{\text {th }}$ November $2011\left(M_{w}=5.6\right)$, known as the first and second earthquakes, respectively, caused extensive damage in the city of Van, the town of Erciş, and in rural areas close to these urban agglomerations. Although the town of Ercis is farther away from the epicentre of the 7.2 event than the city of Van, a greater loss and building collapse actually occurred in Ercis. The second earthquake of $M_{w}=5.6$ caused collapse of buildings that were damaged in the first earthquake in the city of Van. This paper aims to clarify the reasons for the registered causes and effects of the failure of structures in Eastern Turkey.

Earthquakes can cause substantial human and economic losses in earthquake-prone regions. Considering that Turkey is located in a highly seismic area, important factors that should be considered include not only earthquake resistant design engineering principles, but also immediate social reactions after the disaster. Even after the lessons learned from the 1999 Marmara Earthquakes, it should be noted that social consciousness with regard to improper construction practices, such as illicit addition of building storeys, or removal of structural system elements, must be persistently developed. Even though the majority of buildings were affected by non-structural damage such as failure of double layer brick external walls, the buildings designed according to TEC (1997 and 2007) did not have structural damage compared to buildings constructed before 1997. In the same way, the infrastructure (electricity, sewage, and water) and transport (roads, bridges) systems in both Van and Erciş remained unaffected by the two major earthquakes and numerous aftershocks.

\section{REFERENCES}

[1] Eren, K., Uzel, T., Gulal, E., Tiryakioglu, I., Dindar, A.A., Yilmaz, H.: Tectonic Studies in Turkey Using CORS-TR Observations, European Geophysics Union (EGU) General Assembly, 3-8 April 2011, Vienna-Austria.

[2] Reports published in www.afad.gov.tr by Republic of Turkey Prime Ministry Disaster and Emergency Management. (Accessed on December 6th, 2011)

[3] Le Pichon, X., Kreemer, C.: The Miocene-To-Present Kinematic Evolution of the Eastern Mediterranean and Middle East and Its Implications for Dynamics, Annual Review of Earth and Planetary Sciences, 38, 323-351, 2010

[4] McKenzie, D.: Active tectonic of the Mediterranean region, Geophysical Journal of the Royal Astrological Society, 109-185, 1972.

[5] Koçyigit, A.: Neotectonnics and seismicity of East Anatolian. Workshop-2002 on the Geology of East Anatolian. Van, Turkey, 2002.
The following conclusions can be made based on the damage observed in the city centres of Van and Erciş after two major earthquakes described in the paper:

- The observed quality of construction materials is inconsistent with requirements specified in design codes.

- Longitudinal and lateral reinforcement details of RC elements are inconsistent with the earthquake resistant design codes (TEC2007).

- In areas where considerable seismic activities are likely to occur, mixed load bearing systems (shear wall and frame) must be preferred to frame structures.

- Rigorous and effective inspections must be conducted during construction work. Any sort of tolerance of illicit construction practices, such as addition of storeys or modification of structural elements, may lead to catastrophic results in case of an earthquake.

- Basement floors with peripheral shear walls provide an additional stiffness at the foundation level. It was registered that buildings with basements were less affected than those without basement.

- Adobe buildings are prone to shear deformations unless beams are provided. Thus, horizontal and vertical tiebeams and reinforcement should be provided to masonry walls in high seismic areas.

- External infill walls should preferably not be made of twolayer brick walls. If such layered walls are used, they must be mechanically connected with ties.

- Gable walls under high roofs must be framed with tie beams to achieve required stability.

Recorded strong ground-motion waveforms are not of such extent that that should cause serious destruction to engineered structures; however, deficiencies due to poor engineering design and low quality of construction material are the main factors for the human and economic losses registered in Van and Erciş during the studied earthquakes. Consequently, current regulations on the inspection of structures should be improved considerably so as to avoid future disasters.

[6] http://www.emsc-csem.org/ (Accessed on December 2nd, 2011)

[7] http://kyh.deprem.gov.tr/ftpt.htm (Accessed on 02.12.2011)

[8] SeismoSignal (v4.3.0), http://www.seismosoft.com/en/ SeismoSignal.aspx

[9] Trifunac, M.D., Brady, A.G.: A study on the duration of strong earthquake ground motion. Bulletin of the Seismological Society of America 65, 581-626, 1975.

[10] Turkish Earthquake Code, 1997 and 2007

[11] Onen, Y.H., Dindar, A.A., Coşgun, C., Seçkin, E.: 23 Ekim ve 9 Kasım 2011 Tarihli Van Depremleri Yerinde Yapılan Inceleme ve Değerlendirme Raporu, Istanbul Kultur University Site Assessment Report (In Turkish), 2012.

[12] Design and Construction Rules for the Reinforced Concrete Structures (TS-500), Turkish Standard Institute (TSE), 2000 